\title{
Sinking of concrete modules into a sandy seabed: A case study
}

\author{
J.J. Muñoz-Perez ${ }^{\text {a,* }}$, A.B.M. Khan-Mozahedy ${ }^{\text {a }}$, M.G. Neves ${ }^{\text {b }}$, B. Tejedor ${ }^{\text {a }}$, G. Gomez-Pina ${ }^{\text {, }}$ \\ J.M. Campo ${ }^{\mathrm{d}}$, V. Negro ${ }^{\mathrm{d}}$ \\ a Department of Applied Physics, University of Cadiz, Puerto Real 11510, Spain \\ b Laboratorio Nacional de Engenheria Civil (LNEC), 1700-066 Lisbon, Portugal \\ c Coastal Directorate, Ministry of the Environment, 11008 Cadiz, Spain \\ ${ }^{\mathrm{d}}$ Research Group on Marine, Coastal and Port Environment, Universidad Politecnica de Madrid, 28040, Spain
}

A B S T R A C T

\begin{abstract}
Three submerged coastal structures on the sandy seabed at Santa Maria del Mar (SMM) Beach in Southwest Spain were monitored during the six months after installation, starting in November of 2005. The monitoring evaluated the self-burial phenomenon of the 40 precast modular concrete elements of the three structures. Assessment included scouring around the structures, their vertical movement, the sinking velocity of the modules and the resulting beach profiles. Pressure sensors and precision topographies permitted continuous monitoring of the self-burial process for the first time in a full-scale case. Comparison of two bathymetries (one performed immediately prior to installation and another performed six months after installation) indicated slight accretion of the seabed, whereas intermediate topographic surveys indicated extensive scouring around the structures. The three structures began sinking into the sandy bottom platform immediately after placement and continued until they reached the rocky bottom. This study implemented a new methodology using pressure sensors attached to the concrete modules to monitor the structural sinking. Unexpectedly, the average sinking speed was extremely rapid at approximately $3-6 \mathrm{~cm} /$ day; $50 \%$ of the height of the element was reached in three to six weeks. The results of this study are also compared with the results of other full-scale cases. Among other conclusions, data from this study indicated that the sinking rate of the modules in SMM Beach was one order of magnitude greater than the other values.
\end{abstract}

\section{Introduction}

Scouring and liquefaction are two physical phenomena that may cause extensive damage to marine structures. Scouring is one of the threats to the foundational stability of both riverine and maritime structures. Although flow-induced scour around bridge piers has received significant attention for many years, wave-induced scour around marine structures has not become a topic of interest to researchers till the 1990's (Bricker et al., 2012; Matutano et al., 2013; Negro et al., 2014; Sumer and Fredsøe, 2002; Whitehouse, 1998). The presence of marine structures in a coastal flow regime changes the flow pattern in the immediate neighbourhood of the structures. Changes in flow dynamics can increase shear stress in the sandy seabed and thus cause scouring, observed either at the toe of the trunk section or at the round head of the breakwaters (Sumer et al., 2005). Scouring and erosion processes in the sandy foundation of the marine structures cause sinking and structural failure.
In addition to scouring, liquefaction also has a disastrous effect on coastal structures in sandy platforms. Liquefaction is due to not only earthquakes, such as the catastrophic failures in Alaska and Niigata in 1964 (De Alba et al., 1976) or the recent disaster in Japan (Lai et al., 2013), but also waves. Momentary liquefaction occurs during the passage of wave troughs; more importantly, residual liquefaction occurs when the soil on the seabed is subjected to continuous wave loading (see Sumer and Fredsøe (2002) for a more in-depth explanation and Jeng (2003) for a comprehensive review).

Breakwaters are vulnerable to the liquefaction of seabed foundations. Inappropriate design or inadequate maintenance of breakwaters can lead to catastrophic coastal disasters (Jeng et al., 2013). Sutherland et al. (2000) experimented on the scour and deposition around a single detached offshore rubble mound breakwater. Scour and liquefaction around different marine structures has been widely studied in wave flumes. Although this study does not intend to present an exhaustive list of the experimental research previously performed, some noteworthy references and the subject of the research are reviewed in Table 1.

In wave dominated regions, the interaction between the hydrodynamic field and a breakwater has only been investigated either in the 
Table 1

References related to scour and liquefaction in maritime structures.

\begin{tabular}{|c|c|}
\hline Research topic & Authors and year \\
\hline $\begin{array}{l}\text { Mechanics of the scour in the marine } \\
\text { environment }\end{array}$ & Sumer and Fredsøe (2002) \\
\hline $\begin{array}{l}\text { Scour data obtained at roundhead and trunk } \\
\text { of low crested breakwaters }\end{array}$ & Sumer et al. (2005) \\
\hline $\begin{array}{l}\text { The sequence of sediment behaviour during } \\
\text { wave-induced liquefaction }\end{array}$ & Sumer et al. (2006) \\
\hline Effect of seism on liquefaction & Ling et al. (2003) \\
\hline Hydrodynamic forces on pipelines & Cheng et al. (2011) \\
\hline $\begin{array}{l}\text { Liquefaction around pipelines and guidelines } \\
\text { for their stability }\end{array}$ & $\begin{array}{l}\text { Teh et al. (2003), Damgaard et al. } \\
\text { (2006) and USACE, United States } \\
\text { Army Corps of Engineers (2002) }\end{array}$ \\
\hline $\begin{array}{l}\text { Behaviour of cover stones on a liquefiable } \\
\text { soil bed exposed to a progressive wave }\end{array}$ & Sumer et al. (2010) \\
\hline Scour around spherical bodies and self-burial & Truelsen et al. (2005) \\
\hline $\begin{array}{l}\text { Sinking of irregular shape blocks into marine } \\
\text { seabed under wave-induced liquefaction }\end{array}$ & Kirca (2013) \\
\hline $\begin{array}{l}\text { Breaking wave-induced response of } \\
\text { composite breakwater and liquefaction in } \\
\text { seabed foundation }\end{array}$ & Jianhong et al. (2014) \\
\hline Liquefaction around marine structures & Sumer (2014) \\
\hline
\end{tabular}

laboratory and/or in numerical and surprisingly, field studies have been rare (Olsson and Pattiaratchi, 2008; Sumer, 2014). Thus, little information about scour around low crested structures or submerged breakwaters has been obtained from actual case studies. Regrettably, there are inevitable scaling effects in physical modelling related to sandy bottom behaviour; for instance, certain parameters cannot be easily scaled in experimental studies, either geometrically or dynamically. Moreover, numerical models for wave-induced seabed response around marine structures have also been developed, e.g., Jeng et al. (2013), but only experimental data were used for their validation. Extensive experiments have been conducted in different wave flumes (e.g., Kramer et al., 2005); however, only some prototype-scale results have been presented (e.g., Dean et al., 1997 or Stauble and Tabar, 2003). Nevertheless, settlement or sinking has not been commonly surveyed, not even in the exhaustive paper presented by Lamberti et al. (2005), who plotted data of low crested structures in 6 different locations along the European coast.

Results of the continuous monitoring of the self-burial of concrete modules have not yet been presented for a real case. Therefore, the aim of this study is to present the scour and posterior sinking prototype results obtained from examining concrete modular elements placed over a sandy bed in Santa Maria del Mar (SMM) Beach (located in the Gulf of Cadiz, Spain) and to discuss these results in relation to literature data.

\section{Study area}

SMM Beach is a 450 m-long beach with a NNW-SSE orientation located in the Gulf of Cadiz, facing the Atlantic Ocean on the southwest coast of Spain, near the Strait of Gibraltar (Fig. 1).

The Cadiz coast responds to mesotidal characteristics, with two high tides per day separated by $12.42 \mathrm{~h}$. The mesotidal range has a medium neap to spring variation $(1.20-3.80 \mathrm{~m})$. The tidal levels during the observation period are shown in Fig. 2. Additional details about the

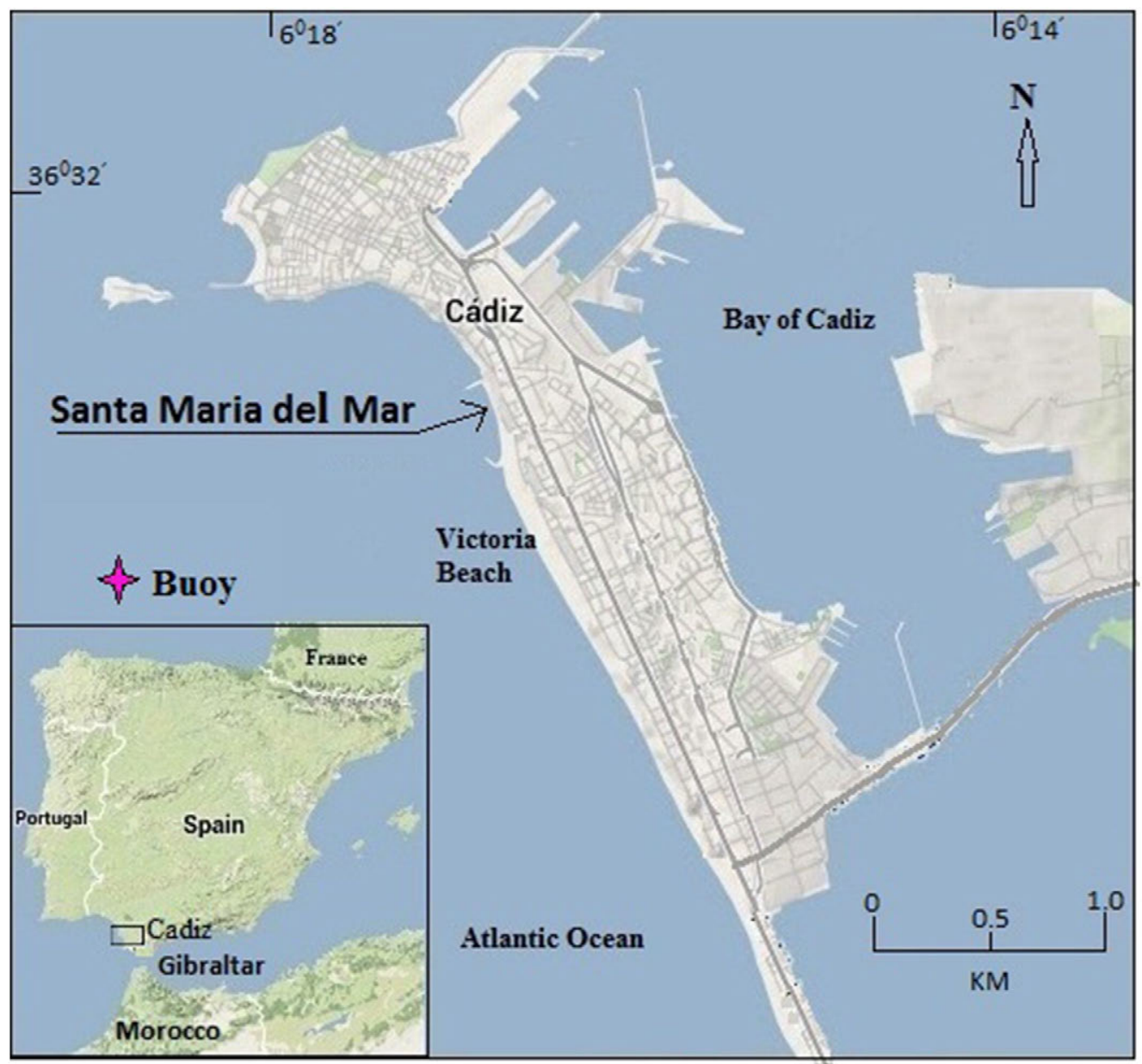




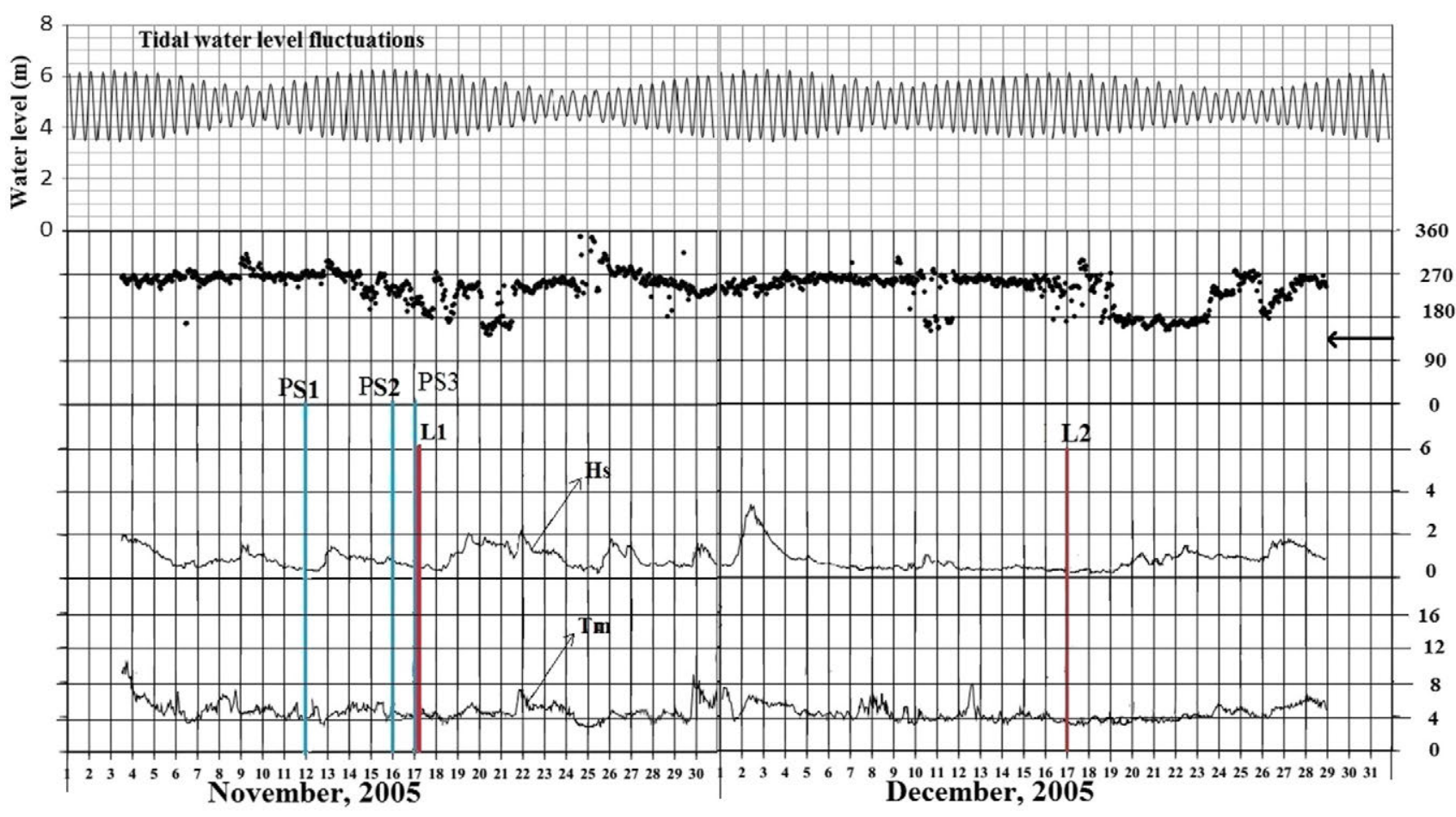

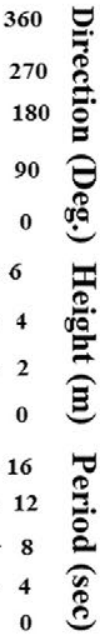

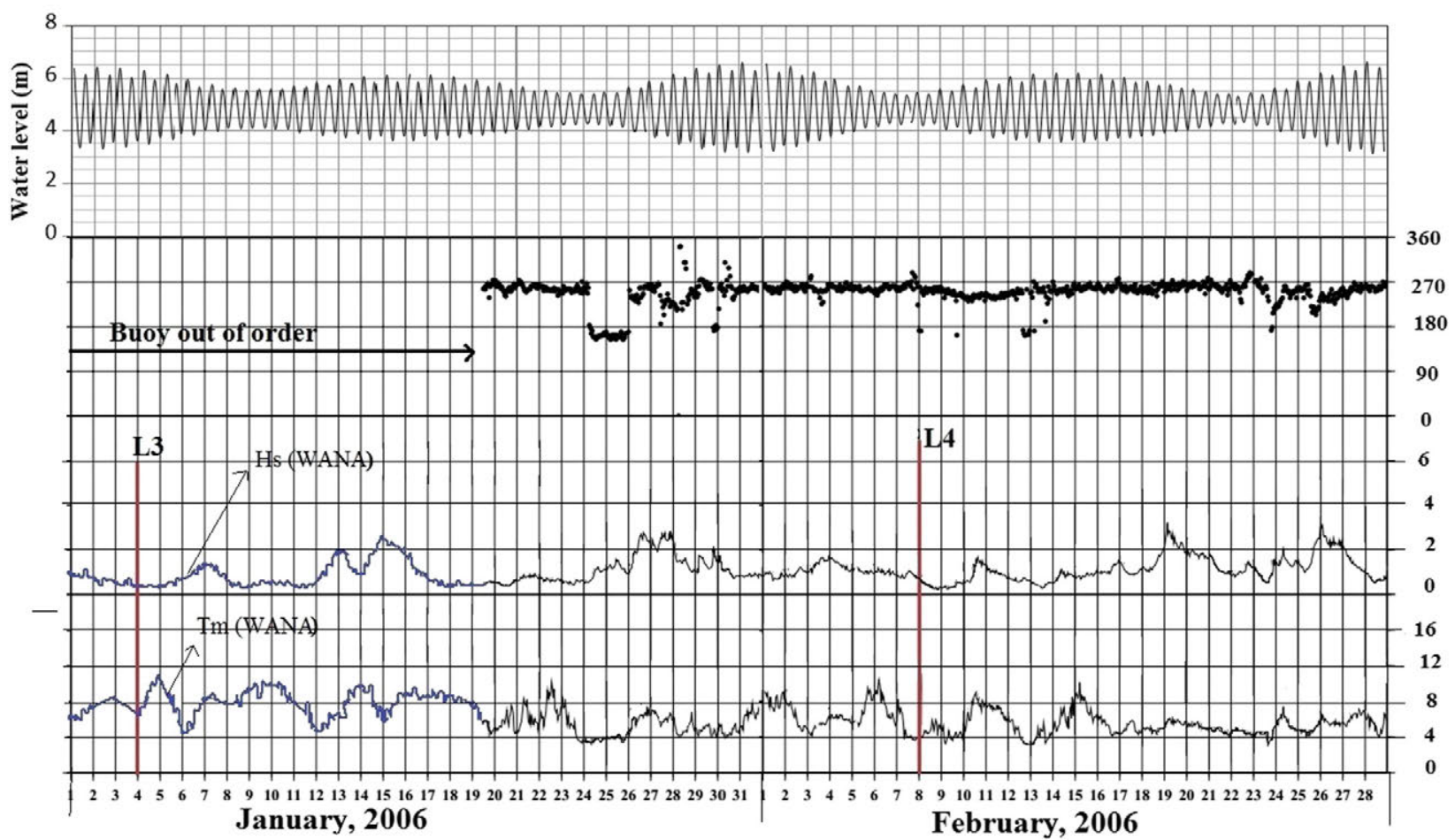

Fig. 2. Wave characteristics during the monitoring interval in SMM Beach: significant wave height and mean period are shown as Hs and Tm as well as the tidal levels. Deployment of structures 1, 2 and 3 on November 12th, 16th and 17th are denoted as PS1, PS2 and PS3, respectively. The four topographic levelling are identified as L1, L2, L3 and L4. Data from the Cadiz buoy are available at www.puertos.es. Results from WANA (a dataset estimated from the wave model analysis) have been used to complete the data for the period during which the buoy was damaged.

tide in the area are provided in Aboitiz et al. (2008) and Muñoz-Perez and Abarca (2009). The incident significant wave heights (Hs), mean periods $(\mathrm{Tm})$ and directions observed during the study period (from October 2005 to February 2006) are shown in Fig. 2. Wave incidence to SMM Beach generally occurs from the west to southwest directions, having a significant wave height range of $0.5-2.0 \mathrm{~m}$ and a mean wave period range of 5.0-12.0 s. Data were obtained from the Triaxys Cadiz buoy (www.axystechnologies.com) located in front of SMM Beach at a depth of $21 \mathrm{~m}$. (www.puertos.es). Nevertheless, there are already investigations underway to validate altimeter data gathered from a satellite (Gomez-Enri et al., 2012).

The dominant sea state typically originates from the WNW, but the most energetic waves occur less frequently and are oriented from the WSW (Fig. 2). On the other hand, eastern (ESE) waves are moderate. These wave conditions generate a dominant littoral drift toward the south and southeast, whereas the storms proceeding from the east 
induce the sand to be transported northward instead. The net quantity of sediment transport has a southward direction, with an average loss value of approximately 70,000 $\mathrm{m}^{3}$ /year (Muñoz-Perez and Medina, 2010). Because of this transport, no berm or dry beach existed at high tide at the end of the 1980s (Muñoz-Perez and Medina, 2005).

The magnitude and direction of the currents could be very important, especially in a place where tidal activity may be dominant. Regrettably, no current metre was placed at that time, and only some general current characteristics of the study region can be given. Data taken during three weeks in summer show that bottom water velocity near the seabed ranges from 0 to $\pm 0.5 \mathrm{~m} / \mathrm{s}$. Nevertheless, only $18 \%$ of the surveyed water particle velocities exceeded $0.2 \mathrm{~m} / \mathrm{s}$ (Mozahedy et al., in press).

Sand on SMM Beach consists of approximately 90-95\% quartz and $5-10 \%$ bioclastic material; the average grain size is approximately $0.25 \mathrm{~mm}$ (Roman-sierra et al., 2013) and the specific gravity of the sand ranges from 1.65 at the submerged beach to 1.71 at the dry beach, being 2.63 the specific gravity of the grains (Roman-Sierra et al., 2014). Geologically, the coast is formed of a bioclastic conglomerate, composed mainly of oyster and pectin shells, and dipping $10^{\circ}$ to the southeast at Victoria Beach (Bernabeu-Tello et al., 2002). Furthermore, this formation is affected by gravity faults of small throw (6-10 m) (Gutierrez-Mas et al., 2003) that divide the littoral region into different zones. The beach located immediately to the south of SMM Beach is named Victoria Beach (Fig. 1) and presents a rocky platform that is relatively horizontal and coincides with the sea level at spring low tides (Muñoz-Perez et al., 2014). However, the rocky stratum of SMM Beach is $2-3 \mathrm{~m}$ deep, and it remains covered by sand. Two groynes were built in 1984 to prevent sediment transport at SMM Beach. They were effective in preventing longshore littoral drift but were not effective in preventing the cross-shore loss, which required the addition of $10-15,000 \mathrm{~m}^{3}$ of sand per year. To reduce the annual addition of sand, a conventional submerged breakwater was placed on the seabed in 1997 by joining the two heads of the groynes (Fig. 3A). The breakwater was $400 \mathrm{~m}$ long, the crest level was $2 \mathrm{~m}$ above the sandy bottom, and the water depth was $3 \mathrm{~m}$. Therefore, the freeboard was $1 \mathrm{~m}$ at the lowest low water level (LLWL). The breakwater was designed based on studies carried out by Ahrens (1989), Vidal et al. (1995) and Gonzalez et al. (1999) to curtail the cross-shore transport of beach sand that had been observed in the past decade. The structure consisted of 2-3 t of stone placed at a 1:2 slope on the sea side and at a 2:3 slope on the beach side (Fig. 3B).

After the winter storms and less than 6 months after the finalisation of the breakwater, an inspection was completed by scuba divers to monitor its behaviour. The stones were not visible because they had sunk completely into the bottom (Fig. 3C) (Medina et al., 2006a). In 1998, a campaign with water spears was performed to find the sandy bottom depth over the breakwater stones. The stones had spread out and were supported on the underlying rocky bottom; the depth of sand over the stones was between $1.0 \mathrm{~m}$ and $1.5 \mathrm{~m}$ (Fig. 3C).

\section{Methodology of the field measurements}

To study the phenomenon that occurred with the submerged structure at SMM Beach, the Coastal Directorate (a dependent of the Ministry of the Environment) decided to use a number of precast

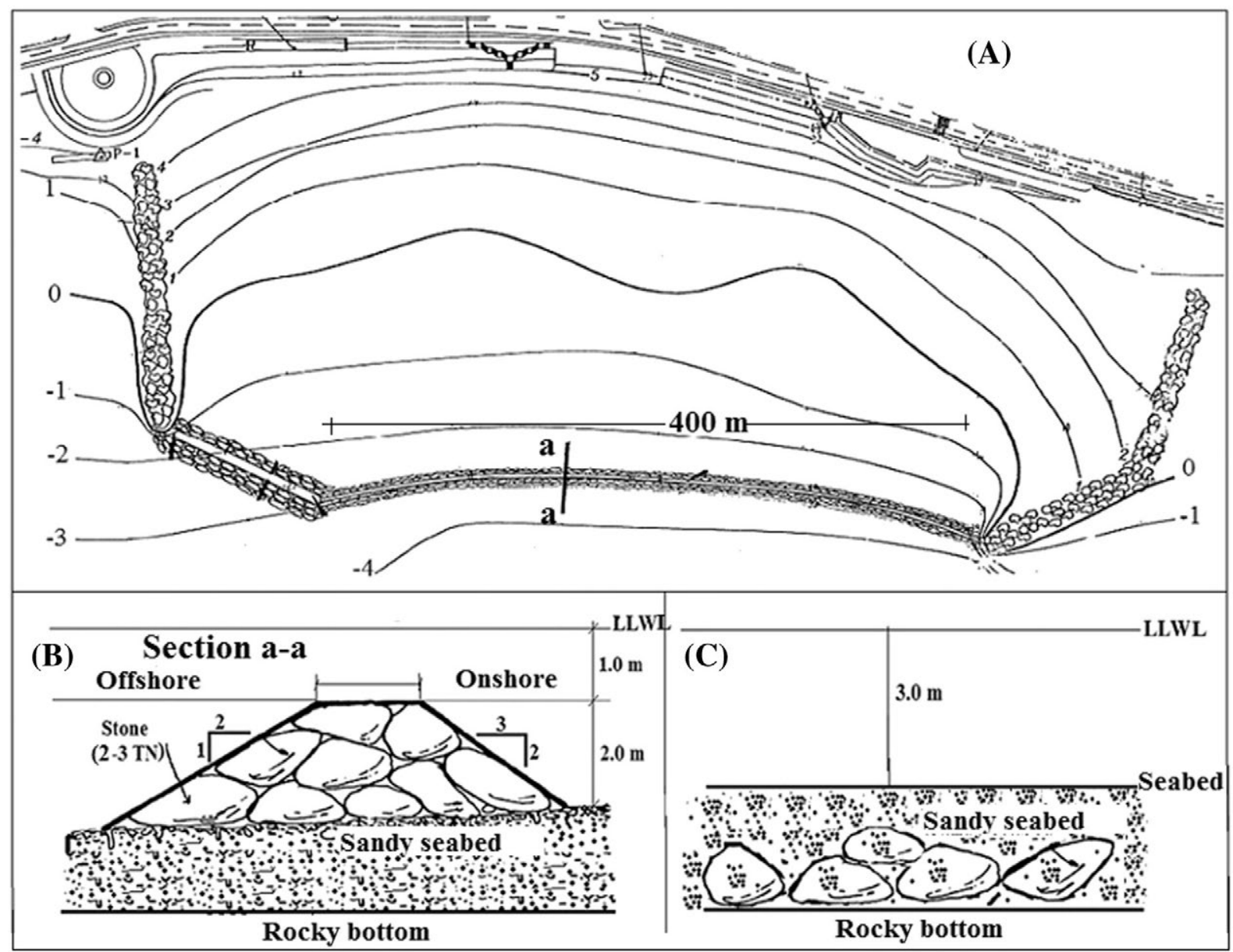

Fig. 3. (A) Aerial view and bathymetry, (B) Section view a-a of the submerged breakwater and (C) position of the stones after sinking phenomenon. 
concrete modular elements patented by the Universitat Politecnica de Valencia (Spain) to examine their utility as well as the possible sinking process (Medina et al., 2006b). The monitoring and control process was undertaken by the Applied Physics Department of the University of Cadiz (Spain).

\subsection{Placement of the precast modular elements}

The submerged modular structures placed between the two groynes were three trapezoidal-shaped structures (Fig. 4A) composed of square- and triangular-shaped modular elements (Fig. 4B and C). A total of 12 square-shaped modular elements with dimensions of $2.5 \mathrm{~m} \times 2.5 \mathrm{~m} \times 2.0 \mathrm{~m}$ (Fig. 5B) and 24 triangular-shaped elements with dimensions of $2.0 \mathrm{~m} \times 2.0 \mathrm{~m} \times 2.5 \mathrm{~m}$ (Fig. $5 \mathrm{C}$ ) were used to construct the three structures. Additionally, 4 triangular elements were placed at the ends of structures 1 and 2 but not at the end of the structure 3 (Fig. 4B). Modules were built in precast concrete with a specific gravity of $2400 \mathrm{~kg} / \mathrm{m}^{3}$.

The three structures are each $8 \mathrm{~m}$ long. Structure 1 was placed in the middle between the two roundheads directly lying on the sandy bottom, structure 2 was closer to the southward groyne, again directly lying on the sandy bottom, and structure 3 was placed closer to the northward groyne, lying over a bed of gravel with a diameter ranging from 1 to $2 \mathrm{~cm}$ and a thickness of approximately $10-15 \mathrm{~cm}$. The extension of this gravel layer was about $3 \mathrm{~m}$ all around the structure. A selfpropelled crane barge was used to place the modular elements (Fig. 5A), and a team of divers tied these elements.

The following controls were carried out to monitor the seabed and structures and to report their possible sinking: bathymetries, precision topographies with pole, pressure sensors (Fig. 5D) and granulometric analysis.

\subsection{Bathymetric surveys and precision topographies}

Two bathymetric surveys were carried out in order to get a general view of the changes experienced along SMM Beach. The first bathymetry was performed just before the placement of the modules (October 2005); the last bathymetry was completed six months later (March 2006), after the winter season. Sounding equipment loaded onto a vessel was used during the bathymetric surveys. The high tide hours were engaged to obtain data as close as possible to the shore thanks at low draught. The procedure permitted errors less than $4 \mathrm{~cm}$ to be maintained. See Muñoz-Perez et al. (2001) for a more detailed description of the method and its accuracy.

Several precision topographic examinations of the structures and the seabed were performed according to the methodology described by Serra and Medina (1996). Metal badges were placed on top of each concrete module (Fig. 4C) to control downward movement. These badges were numbered, allowing for the identification of each module (Fig. 4B). Surveys of the displacement of the badges were carried out periodically by an electronic distance measurer (EDM) from a land base, referred to the LLWL. The pole with the prism on top was placed on the centre of the badges at the spring low tide to reduce the length of the stick and thus the reading error inherent to its inclination. The same methodology was used to measure topographically the seabed within a radius of $25 \mathrm{~m}$ around the three submerged structures. There were several attempts at topographical surveys, but two were unsuccessful because the significant wave height was greater than $0.5 \mathrm{~m}$. Table 2 shows the chronological order of the structural installations in addition to the topographic, bathymetric and other survey campaigns performed.

Regarding the measurement of the rocky bottom level, it was not made during the monitoring of the sinking but some time before, during a geophysical campaign carried out along the Spanish coast in 1991.

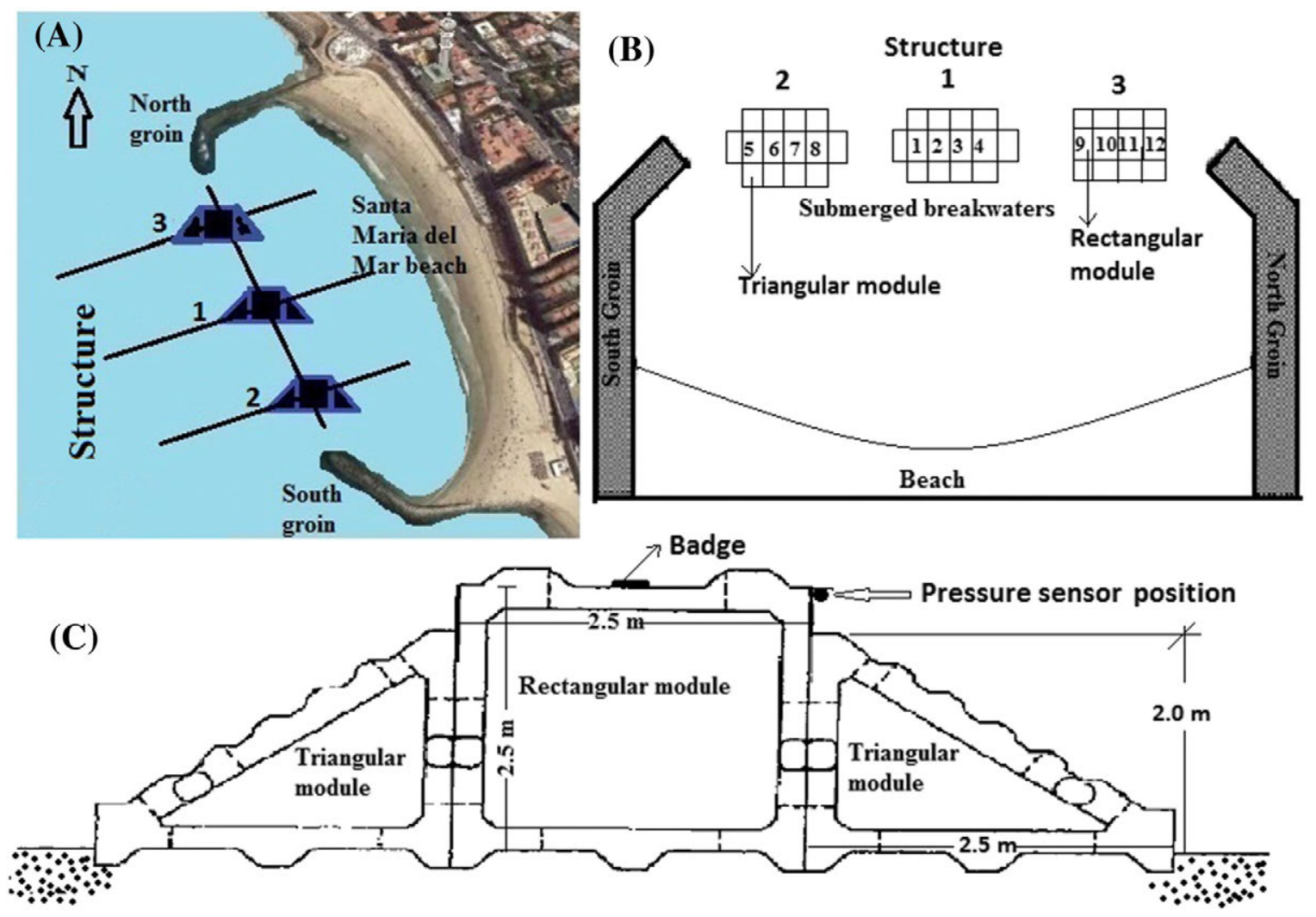

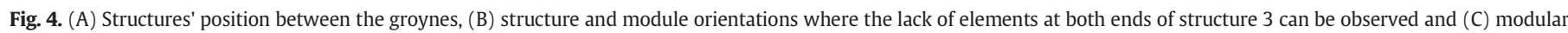
structure's configuration with badge and pressure sensor positions. 


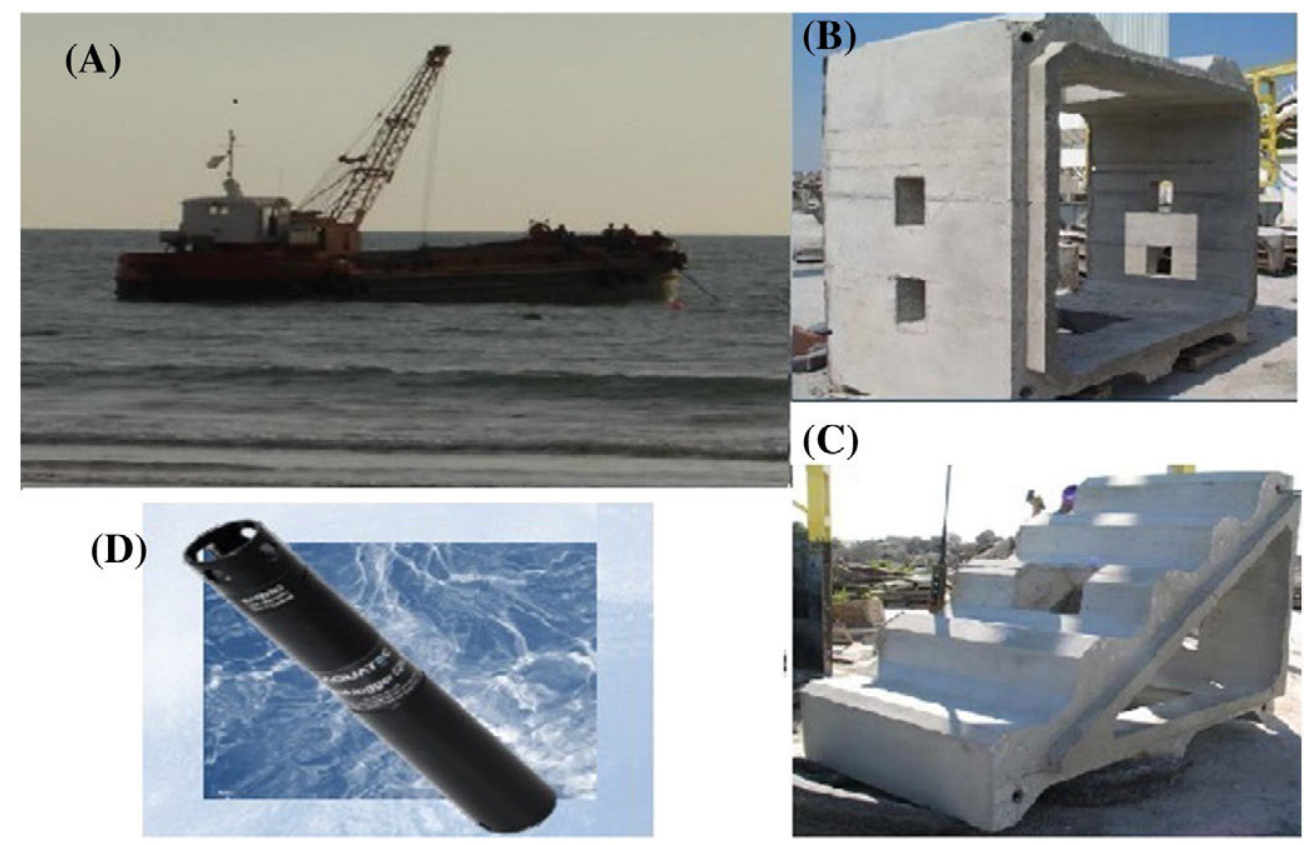

Fig. 5. (A) Crane barge (B) rectangular module (C) TRIANGULAR module and (D) pressure sensor (http://www.aquatecgroup.com/).

The accurate location of the rocky bottom was determined by vibrocores and bathymetric surveying performed according to Geomytsa (1991).

\subsection{Pressure sensors}

Two small pressure sensors (AQUAlogger520) were attached to the upper part of structures 2 and 3 (approximately $5 \mathrm{~cm}$ below the top edge, at the seaward or offshore side) in order to obtain information about the waves, tide and module sinking. AQUAlogger520 (Fig. 5D) is an oceanographic instrument used to record pressure (see http:// www.aquatecgroup.com/). Data collection was initially scheduled for an interval measuring at 1 min every 10 min with a frequency of $1 \mathrm{~Hz}$, and thereby the storage capacity was exhausted after fifteen days. Issues were encountered when periodically downloading the data because the structures were placed near the breaking zone. Thus, the data collection frequency was changed to $1 \mathrm{~min}$ every $20 \mathrm{~min}$, increasing the measurement lifetime to one month (Table 2). LLWL was the reference elevation for the vertical movements.

To the best of the authors' knowledge, the methodology used herein to monitor the sinking of the modules by using pressure sensors is an original technique and is explained below. The sensors installed in the modules measure the total pressure exerted on the instrument. That is, the total pressure is the sum of the pressure due to the water column above the sensor plus the atmospheric pressure at every moment. Then, the height of the sea level over the sensor can be obtained by subtracting the atmospheric pressure.
According to the methodology of Aboitiz et al. (2008), the fluctuations with a period of less than $1 \mathrm{~h}$ were eliminated by filtering the data with a moving average filter A6A6A7 (Godin, 1972). The absolute pressure measurements were transformed to sea level heights relative to the instrument's zero (sensor's reference level) using simultaneous atmospheric pressure measurements taken at hourly intervals in the ROA (Real Observatorio de la Armada). Furthermore, long-period variability was determined by applying the A24A24A25 moving average filter to the residual sea level series (observed minus predicted), and the resulting series were interpreted as the daily sea level variations in the study area.

The mean sea level (MSL) is not constant over the long term due to significant existing seasonal variations (Laiz et al., 2013). However, although the monitoring carried out during this investigation was over a short term, important variations were observed in the MSL in a range of a few days. Such variability cannot be explained except for the sinking of the sensor and thus the module to which it was attached.

\subsection{Granulometric campaigns}

SMM Beach is periodically refilled with sand borrowed from the adjacent beach (Muñoz-Perez and Medina, 2010), has a sandy layer that is approximately 2-3 $\mathrm{m}$ thick over a rocky layer and a porosity of approximately $36.5 \%$ (Roman-Sierra et al., 2014). Sand loss ranges from 10,000 to $15,000 \mathrm{~m}^{3}$ per year. Two granulometric campaigns were conducted at this beach to determine the size of the sand during the study period: the first campaign occurred in September 2005, and

Table 2

Chronology of the structure placements, surveys and monitoring campaigns.

\begin{tabular}{|c|c|c|c|c|c|c|c|c|c|c|}
\hline Granulometric survey (GS) & GS & & & & & & & \multicolumn{3}{|c|}{ GS } \\
\hline Placement of structure (PS) & & & PS & & & & & & & \\
\hline Bathymetric survey (BS) & & BS & & & & & BS & & & \\
\hline Pole topography (PT) & & & PT & PT & PT & PT & & & & \\
\hline Tilting campaign (TC) & & & & & & & & & & $\mathrm{TC}$ \\
\hline Pressure sensor (PS) & & & & & & & & & & \\
\hline Period & September & $\begin{array}{c}\text { October } \\
2005\end{array}$ & November & December & January & February & March & $\begin{array}{l}\text { April } \\
2006\end{array}$ & May & June \\
\hline
\end{tabular}




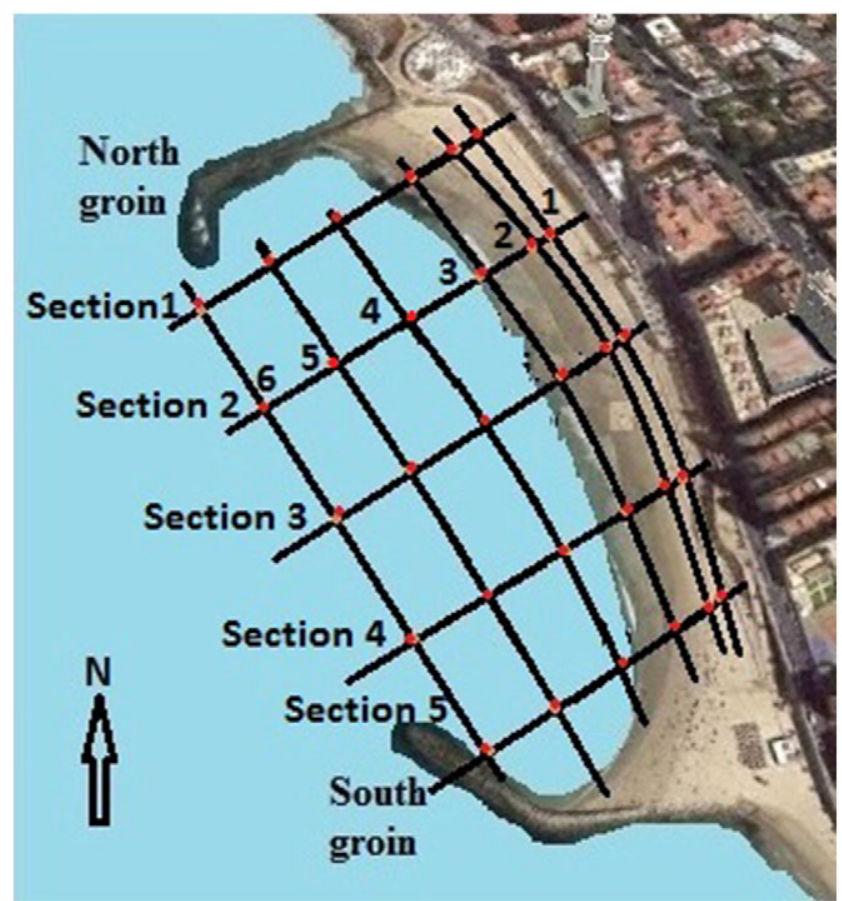

Fig. 6. Location of the sampling points for the granulometric campaigns, showing the 5 profiles and 6 sampling points for each section (points 1 and 6 are the extremes onshore and offshore, respectively).

the second occurred in May 2006. Samples were collected along five transverse profiles with six data points in each section. Section 1 was close to the north groyne, Section 5 was close to the south groyne and the other sections were located at equal distances between the sections. Sample 1 was collected at the highest high water level $(\mathrm{HHWL}=$ LLWL $+3.8 \mathrm{~m}$ ), whereas sample 6 was collected offshore close to the submerged structures. The approximate locations of the sampling points are displayed in Fig. 6. Sixty samples were tested in the laboratory to determine the median size $\left(D_{50}\right)$ of the beach sand.

\section{Results}

\subsection{Bathymetrical surveys and topographical data analysis}

The differences measured between the two bathymetrics performed are shown in Fig. 7. Comparison of contour lines indicates that a sediment accumulation occurred in the entire submerged beach. As there was a seasonal change in the beach profile, this sand accumulation came mostly from the berm erosion.

Topographical data of the badges placed on top of each module of the three structures (Fig. 4B) were obtained during the four campaigns, the dates of which are presented in Table 2. Structures 1, 2 and 3 were deployed on November 12th, 16th and 17th, respectively, and the second topographic monitoring was performed on December 17th. The badge placed on module 4 was damaged during its positioning and was thus eliminated from monitoring. The sinking of the modules was approximately $1.2-1.3 \mathrm{~m}$ in structures 1 and 2 during the first month. For structure 3 , located on a bed of gravel and with no triangular elements placed at the ends, the sinking was slightly lower at approximately $0.8 \mathrm{~m}$ for same period. The behaviour of this structure differed slightly from the beginning (e.g., module 9 was overturned immediately after its placement).

Scouring around all of the structures reached the maximum width and lowest level during the first month after placement (Fig. 8). Backfilling appeared to occur after that first month, until Jan 4th, 2006, with small changes in the level thereafter (Fig. 9).
Sinking nearly ended when backfilling of the sand around the structure was initiated on December 17th. However, structures 1 and 2 still experienced sinking on the order of centimetres until the last monitoring (February 8th, 2006). This second phase of module sinking (Fig. 8) may be explained by other reasons, such as wave impact loads, overburden pressure or consolidation of the sand layer. Self-burial of the concrete modules along with the evolution of the sandy seabed over time for structures 1, 2 and 3 can also be observed in Fig. 9.

As shown in Fig. 3C, the bottom is composed of the stones from the former submerged breakwater and thus has large irregularities. Therefore, considering potential tilting of the modules, a final topographic examination was completed by taking data from the central badge and at the edges of the module. Then, the prism was also placed on the onshore and offshore sides of each module (see Fig. 4C), obtaining the levels shown in Table 3. Topographic levels of the modules at the edges of both structures 2 and 3 (modules 5, 8 and 12) show tilting differences of approximately $20^{\circ}$. Therefore, the tilting experienced (Table 3 ) was slight in structures 1 and 2 except in the modules located at the extremes, as noted above. The other point worth mentioning is that all the modules (except a small variation in $\mathrm{n} .1$ ) are tilted seawards.

Another interesting result from the topographic measurements shown in Fig. 8 is that there is a relevant difference between the sinking experienced by the structures in the first 35 days (approximately 1.3, 1.2 and $0.8 \mathrm{~m}$ for structures 1,2 and 3 , respectively).

\subsection{Data from the pressure sensors}

The pressure sensors provided continuous data that corresponded well with the data obtained by the submerged topographies. A substantial sinking, greater than $1.0 \mathrm{~m}$, occurred for structures 2 and 3 during the first 3 and 6 weeks, respectively (Fig. 10). Then, centimetre-scale oscillations were observed with jumps on the order of decimetres. Both the pressure sensor data and the topographical data are included in Fig. 10 for comparison purposes. The gap observed between the measurements is due to the time elapsed between when the sensor was picked up for data transfer and its subsequent replacement (Table 2).

\subsection{Sand size}

The spatial distribution of the average value of the median sand size $\left(D_{50}\right)$ of the two granulometric campaigns as well as geometric standard deviation values $(\mathrm{mm})$ of the emerged and submerged sand are shown in Table 4. The average median sand size in the emerged beach was approximately $0.33 \mathrm{~mm}$ (Samples $1-3$ ), but the sand size decreased substantially (to approximately $0.23 \mathrm{~mm}$ ) closer the submerged structures (Samples 4-6). The geometric st. deviation value does not vary much in the submerged beach, following a uniform distribution. On the other hand, variation of the geometric st. deviation is larger in the emerged part, showing a more graded pattern.

\section{Discussion}

\subsection{SMM Beach}

According to the topographic data presented in this prototype-scale experiment, all three structures deployed in November 2005 began sinking immediately after their placement on the sandy seabed at SMM Beach. These submerged structures were placed in between the two groynes and close to the breaking wave zone at the LLWL. The topographic analysis of the seabed (Fig. 9) marked extensive scouring around the modules in the first few weeks, and simultaneous module subsidence commenced. A comparison of the initial and final bathymetries of the study area indicates slight sediment accumulation in the entire submerged beach during the winter season (Fig. 7). This sand 

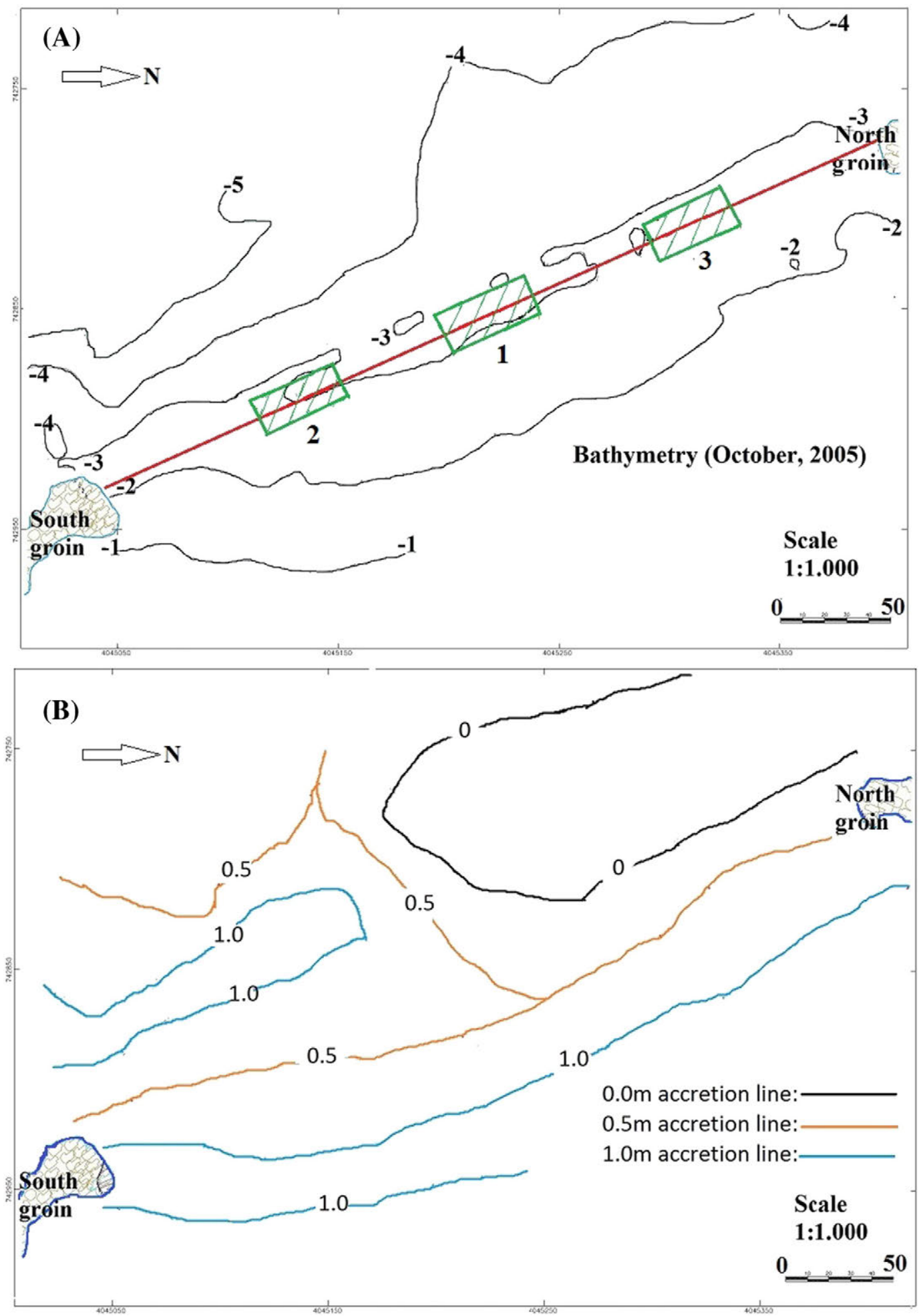

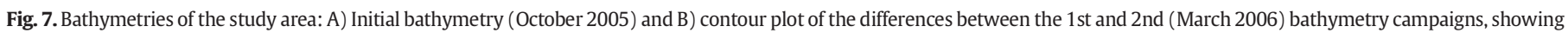
generalised accretion in the entire submerged beach.

came mostly from the erosion of the berm in the usual seasonal change in the beach profile reflecting the natural adjustment to the winter waves. Therefore, this event does not necessarily mean that the presence of the structures increased the sand accumulation.

As noted above, the structures were placed on November 12th, 16th and 17 th, and 4 topographic level procedures were performed immediately after the placement of the structures to set the starting position.
Although the second topographic monitoring was not performed until December 17th, the pressure sensors began collecting data on structures 2 and 3 on November 24th (Fig. 10). The similarity between the topographic and pressure sensor data in Fig. 10 demonstrates the utility and accuracy of this new methodology. Moreover, data taken from this continuous surveying confirm that the foremost sinking of structure 2 ( $1.2 \mathrm{~m}$ ) largely ended by December 4 th, only 19 days after 

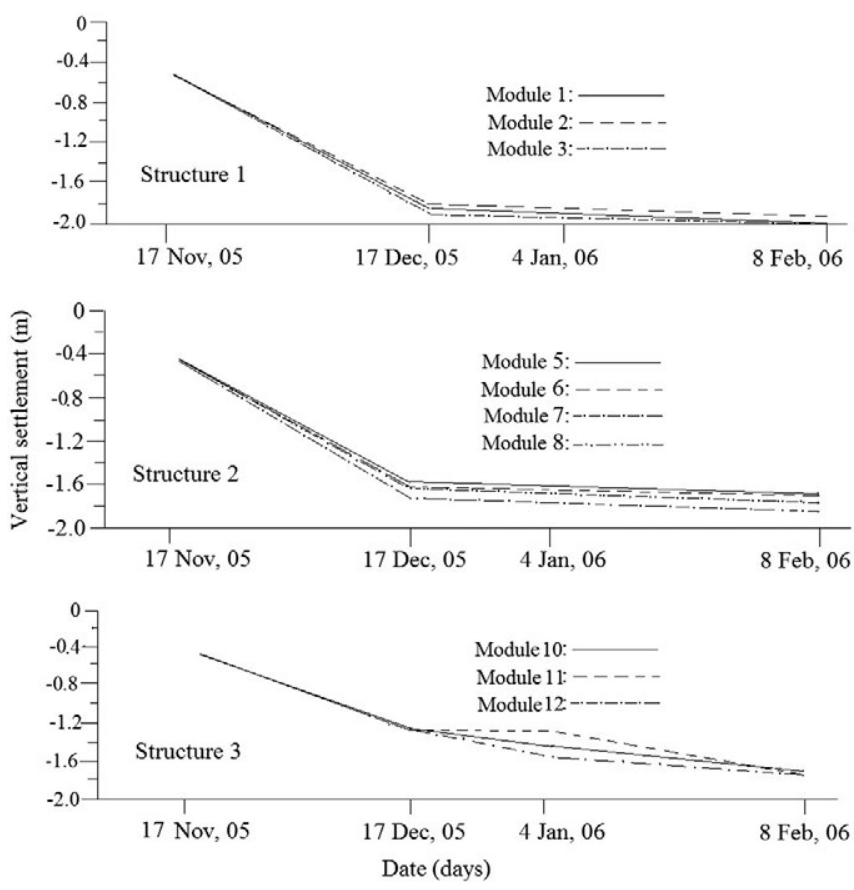

Fig. 8. Levelling of the batches located on top of the different modules.

its placement. In contrast, structure 3 (grounded on a gravel bed) sunk by approximately $0.8 \mathrm{~m}$ in the first 3 weeks and continued to sink another $30 \mathrm{~cm}$ over the following 3 weeks. This difference in its behaviour indicates that the presence of a gravel bed did not change the amount of sinking and only modified slightly the speed of the subsidence. This is probably because the gravel layer (prepared with pebbles $1-2 \mathrm{~cm}$ in diameter, a thickness of $10-15 \mathrm{~cm}$ and an extension of $3 \mathrm{~m}$ all around the structure) was not much of a scour protection. Furthermore, as structure 3 did not have triangular modules at the extremes, block 9 was overturned immediately, likely due to the lack of bounding to the end module.

According to topographic measurements of the central, beach and offshore sides of each module (Table 3 ), the modules located on the centre of the structures (numbers 2, 3, 6, 7 and 10) sunk nearly
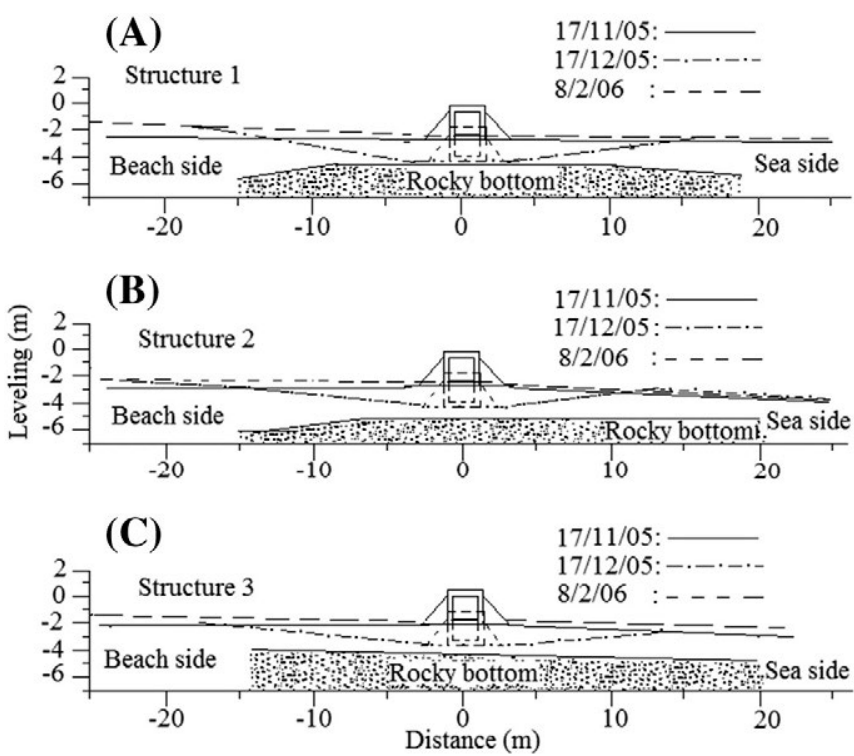

Fig. 9. Seabed profiles close to the structures and their evolution over time.
Table 3

Topographic levelling (in metres) of the central (C), onshore (A) and offshore (B) edges of each module to obtain the tilting experienced at the end of the monitoring period (June 26th, 2006). Datum of reference is the Lowest Low Water Level.

\begin{tabular}{cclllr}
\hline Structure & Module & Onshore side $(\mathrm{A})$ & Offshore Side $(\mathrm{B})$ & Centre $(\mathrm{C})$ & Tilting $\left(^{\circ}\right)$ \\
\hline \multirow{3}{*}{1} & 1 & -2.08 & -1.92 & -2.01 & -3.7 \\
& 2 & -2.85 & -2.86 & -2.85 & 0.2 \\
& 3 & -1.69 & -1.80 & -1.75 & 2.5 \\
& 4 & -2.01 & -2.07 & -2.04 & 1.4 \\
2 & 5 & -0.84 & -1.78 & -1.31 & 20.6 \\
& 6 & -1.80 & -1.79 & -1.80 & -0.2 \\
& 7 & -1.90 & -1.91 & -1.91 & 0.2 \\
& 8 & -1.85 & -2.73 & -2.29 & 19.4 \\
3 & 9 & & & & \\
& 10 & -1.99 & -2.20 & -2.10 & 4.8 \\
& 11 & -2.46 & -2.90 & -2.68 & 10.0 \\
& 12 & -2.40 & -3.25 & -2.82 & 18.8 \\
\hline
\end{tabular}

vertically into the sand with minor tilting. However, the modules on the extremes (numbers 5,8 and 12 ) tilted by approximately $20^{\circ}$. This is probably because the roundhead of breakwaters is prone to higher scour due to streaming and wave contraction (Sumer and Fredsøe, 2002).

Moreover, all the modules were tilted seawards (with the exception of n. 1). Though our modules are not vertical but precast concrete hollow blocks, a plausible explanation could be similar to that of vertical breakwaters which also generally tilt seaward (see Walkden et al., 2001). This is sometimes explained by the differences between the forces under wave crest and wave trough and/or by the wave overtopping. Furthermore, the topographical badge was placed on the centre of the top face of the module, whereas the pressure sensor was located on the edge at the outer face. Thus, the sensor was subjected to larger movements than the badge. Therefore, the sensor could occasionally experience slight ascents (see Fig. 10). The modules that were positioned in the centre of the structures had a smaller rotation, possibly because of their bonds to the adjacent modules on both sides.

Analysis of seabed profiles and pressure sensor measurements indicates that sinking of the modules was nearly completed when scouring stopped (i.e., by December 17 th). At this point, backfilling also started and continued until the seabed reached the equilibrium level by January 4th (Fig. 8). A wave-induced sand transport system backfilled the scoured area around the structures to attain the former profile. The backfilling process was more rapid than the scouring process; the seabed reached the former profile within 2 weeks, whereas the estimated scouring time was approximately 3 weeks. However, it is

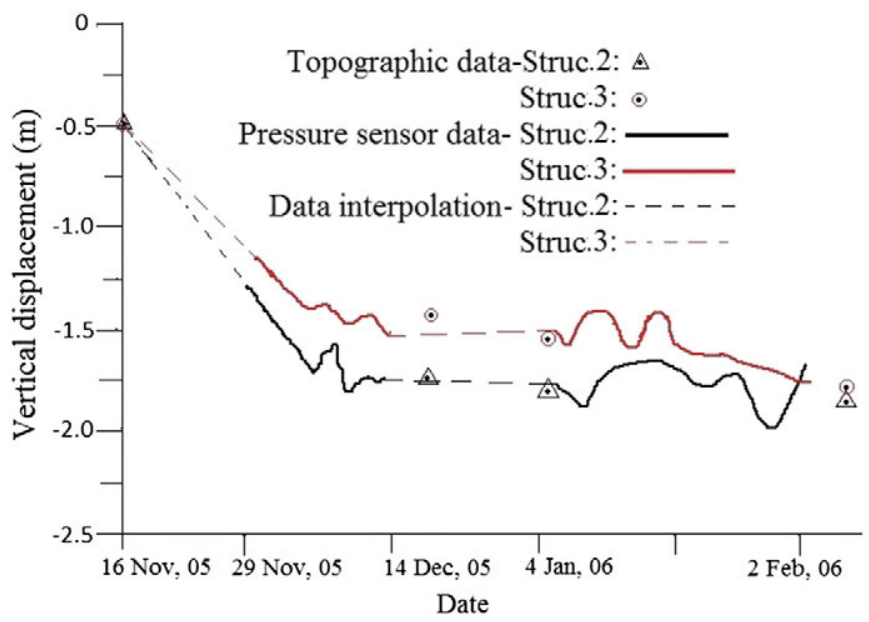

Fig. 10. Comparison of the vertical displacement of the structures 2 and 3 according to the pressure sensor data and topographic levelling. 
Table 4

Average size (D50) and geometric standard deviation values of the emerged and submerged sand at the study site (SMM Beach).

\begin{tabular}{|c|c|c|c|c|c|c|c|c|}
\hline Sample & Level/depth & Section 1 & Section 2 & Section 3 & Section 4 & Section 5 & $\begin{array}{l}\text { Average }(\mathrm{mm}) \\
\text { (Sections } 1-5)\end{array}$ & $\begin{array}{l}\text { Geometric st. deviation } \\
\text { (Sections 1-5) }\end{array}$ \\
\hline 1 & +4.00 & 0.251 & 0.396 & 0.270 & 0.444 & 0.276 & 0.327 & 1.49 \\
\hline 2 & +2.00 & 0.267 & 0.318 & 0.373 & 0.440 & 0.266 & 0.333 & 1.84 \\
\hline 3 & 0.00 & 0.328 & - & 0.354 & - & 0.365 & 0.349 & 2.01 \\
\hline Average (samples 1-3) & & 0.282 & 0.357 & 0.332 & 0.442 & 0.302 & 0.336 & \\
\hline St. deviation (samples $1-3$ ) & & 1.41 & 1.92 & 1.97 & 2.12 & 1.53 & & \\
\hline 4 & -1.00 & 0.357 & 0.295 & 0.264 & 0.330 & 0.345 & 0.318 & 1.57 \\
\hline 5 & -2.00 & 0.230 & 0.259 & 0.209 & 0.213 & 0.283 & 0.239 & 1.46 \\
\hline 6 & -3.00 & 0.217 & 0.242 & 0.192 & 0.247 & - & 0.224 & 1.42 \\
\hline Average (samples 4-6) & & 0.268 & 0.265 & 0.222 & 0.263 & 0.314 & 0.260 & \\
\hline $\begin{array}{l}\text { Geometric } \\
\text { st. deviation (samples 4-6) }\end{array}$ & & 1.57 & 1.44 & 1.38 & 1.59 & 1.53 & & \\
\hline
\end{tabular}

generally expected that the timescale of wave-induced backfilling is slower than scouring (Sumer et al., 2012). Looking at Fig. 7, it can be seen that a general accretion occurred all around the study area. And as stated before, this sand came mostly from the erosion of the berm in the usual beach profile change after a storm. Therefore, there are not enough data to establish a relationship between the wave or tidally induced currents and the scour-backfilling phenomena. Hence, the need to instal a current metre in future field campaigns becomes clear.

Although scouring was stopped and backfilling started after the first three weeks, further sinking of the modules on the order of centimetres (approximately $0-10 \mathrm{~cm}$ in structures 1 and 2 and approximately 20$30 \mathrm{~cm}$ in structure 3 ) continued (see Figs. 8 and 10). This second sinking stage may also be explained by gradual sinking due to wave impacts and consolidation of the sand layer beneath the structures.

Even though liquefaction was not directly detected during this study, the absence of liquefaction cannot be asserted either. Sakai et al. (1994) were successful in producing the liquefaction phenomenon in a U-shaped tank with sands of $0.25 \mathrm{~mm}$ diameter, similar to the size of the submerged sands close to the structures at SMM Beach. Nevertheless, topographic monitoring data and the resulting seabed profiles (Figs. 8 and 9) confirm extensive scour, not liquefaction, as the primary cause of the sinking of the modules.

The wave characteristics at SMM Beach (Fig. 2) indicate a wave direction from $180^{\circ}$ to $270^{\circ}$, a range of incident wave heights of $0.5-$ $2.0 \mathrm{~m}$ and a wave period of approximately $5-12 \mathrm{~s}$ during the monitoring (October 2005 to February 2006). During the period when the modules exhibited larger sinking (i.e., between November and December 2005), two storms occurred that caused significant wave heights of approximately $2 \mathrm{~m}$ (November 19-23th and 26-27th), and another storm produced significant wave heights greater than $3.5 \mathrm{~m}$ (December 3-4th). Nevertheless, the continuous linear sinking observed in Fig. 10 went on even between and after the storms, when a steady sea remained constant with wave heights lower than $0.5 \mathrm{~m}$ (December 4-20th). This outcome leads to the hypothesis that the scour and subsequent self-burial of these submerged structures might not necessarily require large waves, such as those of storms or generated by earthquakes. In this sense, Gallop et al. (2012) have already stated that to fully explain changes at broader scales (such as inter-annual and seasonal changes) an understanding at finer scales (such as during sea breezes, storm events and single waves) was necessary. Three additional storms occurred over the next 2 months, each with wave heights, wave periods and wave directions of the same order of magnitude. No further sinking of the modules was observed but no conclusions could be extracted from this fact, as the modules were already supported on the rocky bottom. Nevertheless, this result indicates the need for further research and the execution of similar experiments during the summer season.

In summary, in the monitoring study presented herein, precast concrete modules ( $2.5 \mathrm{~m}$ high) were buried between 1.20 and $1.30 \mathrm{~m}$ deep in the sandy seabed (i.e., 50\% of their height). However, the tilting analysis (Table 3 ) indicates that the sinking stopped when the modules grounded on the rocky bottom. Thus, it is unclear whether the vertical displacement would have progressed if the blocks had been resting on a sandy stratum of deeper depth. The pressure sensor data (Fig. 10) indicate that structure 2 sunk by approximately $1.1 \mathrm{~m}$ over 20 days. Therefore, the average rate of sinking (or scouring) was approximately $1.5 \mathrm{~m} /$ month (further comparisons will be presented below).

\subsection{Comparison with the results reported in other full-scale cases}

There are limited data on the scour and sinking of breakwater modules in full-scale cases in the literature and no previous studies have involved continuous surveying. Although the material, shape and size of the tested modules as well as the contour conditions (e.g., tidal range, waves, nature of the bottom) were not identical, the results presented by various authors are summarised in Table 5 , and a discussion of these results is provided below.

- Sinking speed: As noted above, the pressure sensors permitted the surveying of an immediate sinking speed, ranging from 3 to $6 \mathrm{~cm} /$ day. The average sinking speed at SMM Beach was approximately $1.5 \mathrm{~m} / \mathrm{month}$. This value is one order of magnitude greater than the values obtained in other studies. The time for most sinking to occur was only 3 weeks, whereas in other studies, the sinking lasted from 4 months to a few years. It cannot be confirmed whether this discrepancy is due to some particular characteristics at SMM Beach or because the monitoring level techniques were carried out at a higher frequency. The latter case would indicate that the methodology presented herein would be the only recommended method to follow in the future. The only comparable value $(0.55 \mathrm{~m} / \mathrm{month})$ was obtained from an experiment in Palm Beach, FL, after a hurricane. Moreover, there are some locations where the sinking speed is almost negligible, such as Ostia and Lido di Dante, Italy or Cape May, NJ. The reasoning behind these results remains unclear.

- Rocky bottom: The existence of a rocky bottom under the sand layer limits the sinking depth, but its influence on the sinking itself or facilitating another physical phenomenon (e.g., liquefaction) is unclear.

- Sinking over the element height rate $\left(\mathrm{s} / \mathrm{h}_{\mathrm{e}}\right)$ : According to Sumer and Fredsoe's results (2002) in laboratory experiments, the main subsidence was approximately $50 \%$ of the height of the element placed in sandy seabed, similar to the values found in the present study. Dean et al. (1997) reported a measurement campaign around one reef in Palm Beach, FL, immediately after a hurricane; the sinking was $0.84 \mathrm{~m}$ over one month $\left(\mathrm{s} / \mathrm{h}_{\mathrm{e}}=47 \%\right)$, whereas the sinking was only $0.60 \mathrm{~m}$ in 8 months $\left(\mathrm{s} / \mathrm{h}_{\mathrm{e}}=33 \%\right)$ in the elements placed thereafter. In contrast, Stauble and Tabar (2003) obtained an estimation that varied greatly $\left(\mathrm{s} / \mathrm{h}_{\mathrm{e}}=8-107 \%\right)$ for the Prefabricated Erosion Prevention (PEP) Reefs.

- Rocky or geotextile bottom filter: Stauble and Tabar (2003) established that the use of a thick filter geotextile placed under the 


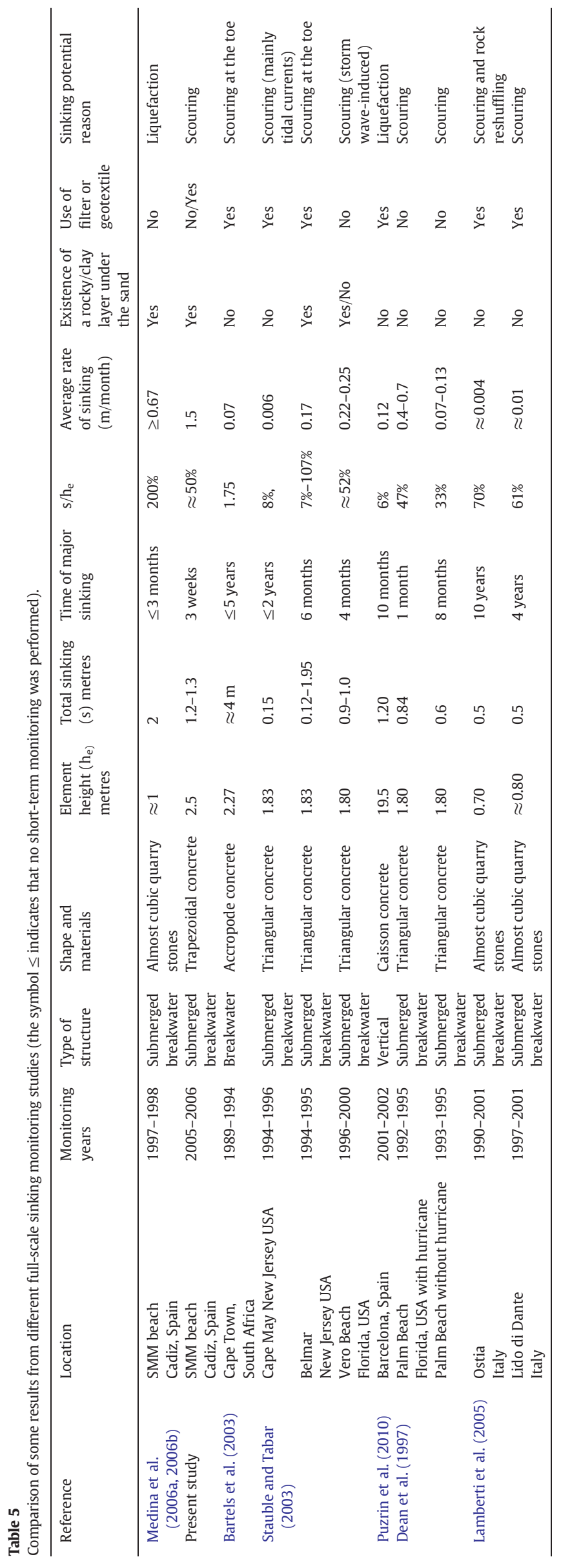

units appeared to limit settling. Nevertheless, at SMM Beach, the placement of a thin layer of gravel on the sandy bottom where structure 3 was supported did not limit the sinking depth; instead, it only slightly reduced the sinking speed. Regrettably, the geometry of the gravel protection used herein (pebbles $1-2 \mathrm{~cm}$ in diameter, a thickness of $10-15 \mathrm{~cm}$ and an extension of $3 \mathrm{~m}$ all around the structure) was probably not much of a scour protection. Therefore, a generalisation of the interpretation of these results is not possible.

- Dimensions of the elements: The dimensions of the elements were some of the more steady parameters in this study. The sizes of the solid quarry stones range from 0.7 to $1 \mathrm{~m}$, whereas the heights of the hollow, precast concrete elements vary from 1.80 to $2.50 \mathrm{~m}$.

- Wave energy: Hurricanes or storms appear to accelerate the sinking phenomenon (see the case of FL for the same module and same location, Table 5); however, the absence of large storms does not preclude the sinking of elements at SMM Beach. Furthermore, the higher energy wave does not necessarily cause more scour or sinking. The worst environment for scour and displacement appears when the waves are breaking and several times (see Fig. 2) a combination of wave height and tidal level induces the wave breaking at the depth of structures. This result suggests the need to perform similar experiments in the summer when a small, steady wave height is more likely.

Further research considering the influence of several conditioning factors (e.g., the existence of a tidal range, an underlayer rocky bottom or a filter geotextile) in the sinking of the elements of a submerged breakwater is necessary.

\section{Conclusions}

In this paper, the sinking of 40 precast concrete modules into a sandy seabed was investigated by analysing data from actual case monitoring. The use of pressure sensors bound to two of the aforementioned precast modules permitted continuous monitoring in a full-scale case for the first time. The major findings of this study are as follows:

- The sinking of modules in a near-shore sandy seafloor started immediately after placement and ended 3 weeks later. The sinking speed was $1.5 \mathrm{~m} / \mathrm{month}$ until the modules reached the rocky bottom, a depth coincidental with $50 \%$ of the height of the element.

- Placement of the modules on the gravel bed foundation used herein did not influence the absolute value of the sinking depth and did not prevent sinking (probably due to its small size and thickness). Instead, the gravel bed only reduced the speed, doubling the sinking time from three to six weeks.

- The modules located on the centre of the structures sunk nearly vertically into the sand with minor tilting. However, the modules on the extremes tilted by approximately $20^{\circ}$.

- The absence of lateral support at the extreme of structure 3 was likely the cause of the immediate overturn of the module located there.

- Wave-structure interaction due to the placement of modules close to the breaking zone (at LLWL) resulted in extensive scour and sinking. The scouring depth (approximately $1.2-1.3 \mathrm{~m}$ ) was similar to the sinking depth. Regrettably, no current metre was placed at the study area during the monitoring and, therefore, establishment of a relationship between the wave or tidally induced currents and the scour-backfilling phenomena was not possible. Hence, the need to instal a current metre in future field campaigns becomes clear.

- When scouring was nearly concluded, backfilling began to fill the scour hole due to a natural sand transport process. Backfilling occurred more rapidly than scouring, and the seabed reached its former profile within 2 weeks. 
- Although sinking due to scouring stopped, the modules continued to sink through gradual penetration on the order of centimetres $(0-10 \mathrm{~cm})$.

- For future similar research, the coordinates of two points on the top face of the modules (e.g., the edges of the onshore and offshore sides) should be measured to account for any tilting that may occur during the sinking process.

Regarding the comparison of the scarce prototype data found in the literature, we note the following:

- There were a large number of variables that influence the sinking process and an insufficient number of data points available to draw valid conclusions.

- A series of experiments should be completed worldwide, taking into account that the sinking of the elements may occur in a matter of days. Moreover, further consideration should be given to the tidal range, sediment properties and nature of the bottom, wave characteristics, depth and freeboard of the structures at the deployment location, shape and size of the elements, the presence of an underlayer rocky bottom and the existence of a gravel or geotextile mattress.

Finally, the results presented herein suggest that continuing to measure prototype cases will help to improve the calibration and validation of laboratory experiments and computational models.

\section{Acknowledgements}

The authors are grateful to Professor Josep Medina from Universitat Politecnica de Valencia and two unknown reviewers for their critical comments, which greatly improved the manuscript.

\section{References}

Aboitiz, A., Tejedor, B., Muñoz-Perez, J.J., Abarca, J.M., 2008. Relation between daily variations in sea level and meteorological forcing in sancti petri channel (SW Spain). Cienc. Mar. 34, 491-501.

Ahrens, J.P., 1989. Stability of reef breakwaters. J. Waterw. Port Coast. Ocean Eng. 115 221-234.

Bartels, A., Phelp, D., Kloss, M., 2003. Repair of an Accropode Breakwater: 5 years on, COPEDEC VII, Colombo, Paper 003.

Bernabeu-Tello, A., Muñoz-Perez, J., Medina-Santamaria, R., 2002. Influence of a rocky platform in the profile morphology: Victoria Beach, Cadiz (Spain). Cienc. Mar. 28 (2), 181-192.

Bricker, J.D., Francis, M., Nakayama, A., 2012. Scour depths near coastal structures due to the 2011 Tohoku Tsunami. J. Hydraul. Res. 50 (6), 637-641.

Cheng, X., Wang, Y., Wang, G., 2011. Hydrodynamic forces on a large pipeline and a small pipeline in piggyback configuration under wave action. J. Waterw. Port Coast. Ocean Eng. 138, 394-405.

Damgaard, J.S., Sumer, B.M., Teh, T., Palmer, A., Foray, P., Osorio, D., 2006. Guidelines for pipeline on-bottom stability on liquefied noncohesive seabeds. J. Waterw. Port Coast. Ocean Eng. 132, 300-309.

De Alba, P.A., Chan, C.K., Seed, H.B., 1976. Sand liquefaction in large-scale simple shear tests. J. Geotech. Eng. Div. 102, 909-927.

Dean, R.G., Chen, R., Browder, A.E., 1997. Full scale monitoring study of a submerged breakwater, Palm Beach, Florida, USA. Coast. Eng. 29, 291-315.

Gallop, S.L., Bosserelle, C., Pattiaratchi, C.B., Eliot, I., Haigh, I.D., 2012. The influence of calcarenite limestone reefs on beach erosion and recovery, from seconds to years. Coast. Eng. Proc. 33. http://dx.doi.org/10.9753/icce.v33.sediment.72.

Geomytsa, 1991. Marine geophysical study between the Puerco tower and the Castle of San Sebastian (Cadiz). Coastal Directory, Ministry of Public Works, Madrid (Ref. 00-372 5 vols (in Spanish)).

Godin, G., 1972. The Analysis of Tides. Univ. of Toronto Press, Ontario (264 pp.).

Gomez-Enri, J., Aboitiz, A., Tejedor, B., Villares, P., 2012. Seasonal and interannual variability in the Gulf of Cadiz: validation of gridded altimeter products. Estuar. Coast. Shelf Sci. 96, 114-121.

Gonzalez, M., Medina, R., Losada, M., 1999. Equilibrium beach profile model for perched beaches. Coast. Eng. 36, 343-357.

Gutierrez-Mas, J., Moral, J., Sanchez, A., Dominguez, S., Muñoz-Perez, J., 2003. Multicycle sediments on the continental shelf of Cadiz (SW Spain). Estuar. Coast. Shelf Sci. 57, 667-677.

Jeng, D.S., 2003. Wave-induced sea floor dynamics. Appl. Mech. Rev. 56, 407-429.

Jeng, D., Ye, J., Zhang, J., Liu, P., 2013. An integrated model for the wave-induced seabed response around marine structures: model verifications and applications. Coast. Eng. 72, 1-19.
Jianhong, Ye, Dongsheng, J., Liu, P.F., Chan, A.H.C., Ren, W., Changqi, Z., 2014. Breaking wave-induced response of composite breakwater and liquefaction in seabed foundation. Coast. Eng. 85, 72-86

Kirca, V., 2013. Sinking of irregular shape blocks into marine seabed under wave-induced liquefaction. Coast. Eng. 75, 40-51.

Kramer, M., Zanuttigh, B., Van der Meer, J.W., Vidal, C., Gironella, F.X., 2005. Laboratory experiments on low-crested breakwaters. Coast. Eng. 52 (10), 867-885.

Lai, T., Nasseri, A., Yin, Y.J., Katiyar, V., Turel, M., 2013. Modeling Railway Damage due to Shake, Liquefaction, and Tsunami for the 2011 Tohoku Earthquake. International Efforts in Lifeline Earthquake Engineering 38, p. 267.

Laiz, I., Gomez-Enri, J., Tejedor, B., Aboitiz, A., Villares, P., 2013. Seasonal sea level variations in the gulf of Cadiz continental shelf from in-situ measurements and satellite altimetry. Cont. Shelf Res. 53, 77-88.

Lamberti, A., Archetti, R., Kramer, M., Paphitis, D., Mosso, C., Di Risio, M., 2005. European experience of low crested structures for coastal management. Coast. Eng. 52, 841-866.

Ling, H.I., Mohri, Y., Kawabata, T., Liu, H., Burke, C., Sun, L., 2003. Centrifugal modeling of seismic behavior of large-diameter pipe in liquefiable soil. J. Geotech. Geoenviron. Eng. 129 (12), 1092-1101.

Matutano, C., Negro, V., Lopez-Gutiérrez, J.S., Esteban, M.D., 2013. Scour prediction and scour protections in offshore wind farms. Renew. Energy 57, 358-365.

Medina, J.R., Muñoz-Perez, J.J., Gomez-Pina, G., 2006a. Transmission and Reflection of Modular Detached Breakwaters. Coast. Eng. Conf. (ASCE) 30 (5), 4350-4361.

Medina, J., Muñoz-Perez, J.J., Tejedor, B., Gomez Pina, G., Fages, L., 2006b. Actuacion experimental con diques modulares en Santa Maria del Mar. Redes neuronales, socavacion y licuefaccion de arenas. II Congr. Nacional Asociacion Tecnica de Puertos y Costas, pp. 301-322.

Mozahedy, A.B.M., Muñoz-Perez, J.J., Neves, M.G., 2015. Monitoring of the water particle velocity field near the seabed under different wave and tidal scenarios: a real case. Proc. of 5th Int. Conf. on Water and Flood Management (in press).

Muñoz-Perez, J.J., Abarca, J.M., 2009. Effect of wind and atmospheric pressure variations on the mean sea level of salt marshes and estuaries. Rev. Obras Públicas 156, 21-32.

Muñoz-Perez, J.J., Medina, R., 2005. Short-term variability on reef protected beach profiles: an analysis using EOF. Coastal Dynamics 2005: State of the Practicepp. 1-11.

Muñoz-Perez,J.J., Medina, R., 2010. Comparison of long-, medium- and short-term variations of beach profiles with and without submerged geological control.J. Coast. Eng 57, 241-251.

Muñoz-Perez, J.J., Medina, R., Tejedor, B., 2001. Evolution of longshore beach contour lines determined by EOF method. Sci. Mar. 65, 393-402.

Muñoz-Perez, J.J., Roman-Sierra, J., Navarro-Pons, M., Neves, M.G., del Campo, J.M., 2014. Comments on "confirmation of beach accretion by grain-size trend analysis: Camposoto beach, Cádiz, SW Spain” by E. Poizot et al.(2013). Geo-Mar. Lett. 34 (1), 75-78.

Negro, V., Lopez-Gutierrez, J.S., Esteban, M.D., Matutano, C., 2014. Uncertainties in the design of support structures and foundations for offshore wind turbines. Renew. Energy 63, 125-132.

Olsson, D., Pattiaratchi, C., 2008. Field measurements of rip currents in the vicinity of coastal structures. Coast. Eng. Proc. 31, 914-926.

Puzrin, A.M., Alonso, E.E., Pinyol, N.M., 2010. Caisson failure induced by liquefaction: Barcelona Harbour, Spain. Geomechanics of Failures. Springer, Netherlands, pp. 85-148.

Roman-Sierra, J., Muñoz-Perez, J.J., Navarro-Pons, M., 2013. Influence of sieving time on the efficiency and accuracy of grain-size analysis of beach and dune sands. Sedimentology 60, 1484-1497. http://dx.doi.org/10.1111/sed.12040.

Roman-Sierra, J., Muñoz-Perez, J.J., Navarro-Pons, M., 2014. Beach nourishment effects on sand porosity variability. Coast. Eng. 83, 221-232.

Sakai, T., Asce, M., Gotoh, H., Yamamoto, T., 1994. Block subsidence under pressure and flow. Coast. Eng. Proc. 1 (24), 1541-1552.

Serra, J., Medina, J.R., 1996. Beach monitoring program of Valencia (Spain). 25th Int. Conf. on Coastal Engineering Proceedings 3, pp. 2871-2883.

Stauble, D.K., Tabar, J.R., 2003. The use of submerged narrow-crested breakwaters for shoreline erosion control. J. Coast. Res. 19 (3), 684-722.

Sumer, M., 2014. Liquefaction Around Marine Structures. World Scientific Publ. Co.

Sumer, B.M., Fredsøe, J., 2002. The Mechanics of Scour in the Marine Environment. World Scientific, Singapore.

Sumer, B.M., Fredsøe, J., Lamberti, A., Zanuttigh, B., Dixen, M., Gislason, K., Di Penta, A.F., 2005. Local scour at roundhead and along the trunk of low crested structures. Coast. Eng. 52, 995-1025.

Sumer, B.M., Hatipoglu, F., Fredsøe, J., Sumer, S.K., 2006. The sequence of sediment behaviour during wave-induced liquefaction. Sedimentology 53 (3), 611-629.

Sumer, B.M., Dixen, F.H., Fredsøe, J., 2010. Cover stones on liquefiable soil bed under waves. Coast. Eng. 57 (9), 864-873

Sumer, B.M., Petersen, T.U., Locatelli, L., Fredsøe, J., Musumeci, R.E., Foti, E., 2012. Backfilling of a scour hole around a pile in waves and current. J. Waterw. Port Coast. Ocean Eng. 139 (1), 9-23.

Sutherland, J., Whitehouse, R.J.S., Chapman, B., 2000. Scour and deposition around a detached rubble mound breakwater. Coastal Structures' 99, Santander, Spain.

Teh, T., Palmer, A., Damgaard, J., 2003. Experimental study of marine pipelines on unstable and liquefied seabed. Coast. Eng. 50 (1), 1-17.

Truelsen, C., Sumer, B.M., Fredsøe, J., 2005. Scour around spherical bodies and self-burial. J. Waterw. Port Coast. Ocean Eng. 131, 1-13.

USACE, United States Army Corps of Engineers, 2002. Coastal Engineering Manual. http:// chl.erdc.usace.army.mil/cem (EM 1110-2-1100)

Vidal, C., Losada, M.A., Mansard, E.P., 1995. Stability of low-crested rubble-mound breakwater heads. J. Waterw. Port Coast. Ocean Eng. 121, 114-122.

Walkden, M.J., Wood, D.J., Bruce, T., Peregrine, D.H., 2001. Impulsive seaward loads induced by wave overtopping on caisson breakwaters. Coast. Eng. 42 (3), 257-276.

Whitehouse, R. (Ed.), 1998. Scour at Marine Structures: a Manual for Practical Applications. Thomas Telford. 